\title{
PENGARUH PENUNDAAN PEMOTONGAN TALI PUSAT TERHADAP LAMA LAHIR PLASENTA, LAMA PUPUT TALI PUSAT DAN KEBERHASILAN INISIASI MENYUSU DINI (IMD) DI RB ANNY RAHARDJO DAN RB ROSNAWATI JAKARTA TIMUR
}

\author{
Munawaroh $^{1)}$, Ajeng Rakhma Sejati ${ }^{2)}$ \\ Program studi DIII-Kebidanan Universitas MH.Thamrin \\ muna2880@yahoo.com
}

\begin{abstract}
ABSTRAK
Penundaan pengkleman dan pemotongan tali pusat (Delayed Cord Clamping) adalah praktik penundaan pengkleman dan pemotongan tali pusat dimana tali pusat tidak dijepit atau dipotong sampai setelah denyutan berhenti atau sampai setelah plasenta lahir seluruhnya (Mercer, 2006). Penelitian ini bertujuan untuk mengetahui lamanya pelepasan plasenta, lama puput tali pusat dan keberhasilan Inisiasi Menyusu Dini pada ibu yang melahirkan normal dengan dilakukan tindakan penundaan pemotongan tali pusat dan yang tidak dilakukan penundaan pemotongan tali pusat. Penelitian ini menggunakan pendekatan kuantitatif dengan metode studi komparatif. Rancangan penelitian dalam penelitian ini menggunakan Case Control. Populasi dalam penelitian ini adalah ibu-ibu yang melahirkan normal pada bulan Maret sampai Juni 2015 di RB Anny Rahardjo dan di RB Rosnawati. Sedangkan sampel dalam penelitian ini adalah ibu-ibu yang melahirkan normal pada bulan April sampai Juni 2015 di RB Anny Rahardjo dan di RB Rosnawati sebanyak 94 responden yang terdiri dari 38 responden yang ditunda pemotongan tali pusatnya dan 56 responden yang segera dipotong tali pusatnya.Tekhnik pengumpulan data dengan cara menggunakan lembar observasi yang berisi data pengamatan secara langsung pada saat proses persalinan serta ceklist yang diisi oleh responden tentang lama puput tali pusat yang akan dikumpulkan kepada peneliti pada kunjungan nifas.Hasil penelitian pada analisis bivariat adalah ibu dengan penundaan pemotongan tali pusat akan mengalami puput tali pusat kurang dari sama dengan 5 hari sebesar $54.5 \%$ sedangkan dengan ibu yang segera dipotong tali pusatnya sebesar 45.5\% dengan RR 1.5 (95\% CI 0.896-2.502). Ibu bersalin dengan penundaan pemotongan tali pusat plasenta akan lahir dalam waktu kurang dari sama dengan 5 menit sebesar $28 \%$ sedangkan yang segera sebesar $72 \%$ dengan RR 0.6 (95\% CI 0.239-1.160). Ibu melahirkan dengan penundaan pemotongan tali pusat akan berhasil melakukan IMD selama 60 menit sebesar $42.2 \%$ sedangkan yang segera sebesar $57.8 \%$ dengan RR 0.5 (95\% CI $0.484-$ 0.689). Secara statistik Ibu melahirkan dengan penundaan pemotongan tali pusat akan lebih cepat mengalami waktu puput tali pusatnya sebesar 1.5 kali dibandingankan dengan yang segera dipotong sedangkan pada lama lahir plasenta dan lama IMD tidak ada perbedaan yang signifikan terhadap waktu lahir plasenta dan lama IMD.
\end{abstract}

Kata Kunci : Tali pusat, penundaan pemotongan tali pusat, plasenta

\section{PENDAHULUAN}

Tali pusat merupakan penghubung antara bayi dengan plasenta. Fungsi tali pusat diantaranya adalah untuk menyalurkan nutrisi dan oksigen dari ibu kepada janin. Pemotongan tali pusat sebelum waktunya lepas, dapat berbahaya bagi bayi yang baru lahir karena membuat mereka dua kali lebih rentan terkena infeksi. Setelah persalinan tali pusat akan lepas dengan sendirinya dari tubuh bayi dalam waktu 3-10 hari.

Ratnasari, dkk dalam penelitiannya tentang Pengaruh Persalinan Lotus Birth/Penundaan Pemotongan Tali Pusat terhadap lama pelepasan plasenta, lama puput tali pusat dan Keberhasilan Bounding Attachement di dapatkan hasil bahwa pelepasan plasenta pada Lotus Birth lebih cepat dibandingkan dengan metode konvensional demikian juga dengan pelepasan tali pusat terhadap persalinan Lotus Birth lebih baik dibandingkan dengan metode konvensional.

Tujuan penelitian ini adalah untuk mengetahui proporsi penundaan pemotongan tali pusat dan pengaruhnya terhadap lama pelepasan plasenta, lama puput tali pusat dan Keberhasilan Inisiasi Menyusu Dini (IMD) 


\section{METODE}

Rancangan penelitian ini menggunakan Case Control yaitu penelitian dimulai dengan mengidentifikasi efek atau penyakit tertentu (kasus) dan kelompok tanpa efek (kontrol). Populasi dan sampel dalam peneliti ini adalah semua ibu bersalin normal pada Maret sampai dengan Juni 2015. Ibu bersalin dengan penundaan pemotongan tali pusat selama 24 jam sebanyak 38 responden dan ibu bersalin yang tidak ditunda pemotongan tali pusatnya sebanyak 56 responden (kontrol).Dalam proses pengumpulan data penelitian ini penulis dibantu oleh seorang bidan dengan menggunakan lembar observasi yang berisi data pengamatan secara langsung pada saat proses persalinan yang meliputi data berapa lama plasenta lepas (menit) dan keberhasilan Inisiasi Menyusu Dini (IMD) selama satu jam setelah bayi lahir. Adapun data pelepasan tali pusat berupa ceklist yang diisiolehresponden yang akan dikumpulkan kepada peneliti pada kunjungan nifasya itu seminggu setelah persalinan. Analisa data menggunakan SPSS 17 dengan analisis univariat dan bivariate.

\section{Tabel 1}

Distribusi Proporsi Lama Puput Tali Pusat, Lama Plasenta Lepas, Lama IMD Pada Tindakan Penundaan Pemotongan Tali Pusat

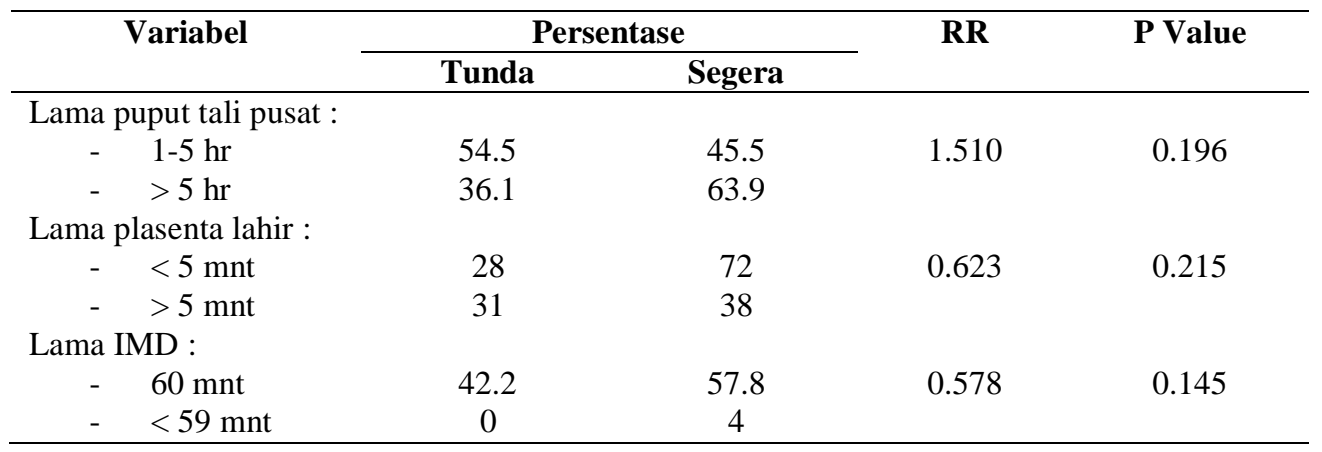

\section{Penundaan Pemotongan Tali Pusat}

Berdasarkan hasil penelitian di dapatkan bahwa ibu yang melahirkan dengan penundaan pemotongan tali pusat masih lebih rendah jika dibandingkan dengan ibu melahirkan yang segera dipotong tali pusatnya. Ibu dengan penundaan pemotongan tali pusat sebesar $40.4 \%$ dan yang segera dipotong tali pusatnya sebesar $59.6 \%$. Amerika merupakan Negara perintis Lotus Birth, hal tersebut sebagai langkah pencegahan infeksi luka terbuka pada tali pusat. Meskipun merupakan suatu fenomena alternative baru penundaan pemotongan tali pusat sudah ada dalam budaya Bali dan budaya Aborigin. Oleh karena itu keputusan untuk melakukan Lotus Birth serta dampak fisiologis yang dapat terjadi karena Lotus Birth merupakan tanggungjawab dari klien yang telah memilih dan membuat keputusan tersebut. Penundaan pemotongan tali pusat yang dilakukan di RB Anny Rahardjo sebenarnya merupakan pilihan dari pasien sendiri setelah mendapatkan penyuluhan dan pendidikan kesehatan dari tenaga kesehatan. Hanya di Rumah Bersalin tertentu saja yang menerapkan penundaan pemotongan tali pusat terhadap pasien-pasiennya karena masih ada pro dan kontra terhadap tindakan ini sehingga belum bias dibuat Standar Operasional Prosedur (SOP) di Indonesia.

\section{Penundaan Pemotongan Tali Pusat Terhadap Lama Puput Tali Pusat}

Berdasarkan hasil penelitian di dapatkan bahwa bayi dari ibu bersalin dengan penundaan pemotongan tali pusat akan mengalami puput tali pusat dalam waktu kurang dari atau sama dengan 5 hari sebanyak $54.5 \%$ dan yang 
lebih dari 5 hari sebanyak $36.1 \%$ sedangkan bayi dari ibu bersalin yang segera dipotong tali pusatnya akan puput dalam waktu kurang dari atau sama dengan 5 hari sebanyak $45.5 \%$ dan yang yang lebih dari 5 hari sebanyak 63.9\%. Dengan RR 1.5 (95\% CI 0.896-2.502) artinya ibu dengan penundaan pemotongan tali pusat akan 1.5 kali lebih cepat puput tali pusatnya dibandingkan dengan ibu bersalin yang segera dipotong tali pusatnya.

Hal ini sesuai dengan hasil penelitian Mercer yang menyatakan bahwa lama waktu puput tali pusat bila nanti dipotongnya rata-rata 3.75 hari sedangkan bila segera dipotong rata-rata puput tali pusat 9.56 hari. WHO menekankan pentingnya penyatuan atau penggabungan untuk asuhan ibu dan bayi. Hal ini dinyatakan dalam Panduan Praktis Asuhan Persalinan Normal (Genewa Swiss, 1997) bahwa Penundaan pengkleman atau tidak diklem sama sekali adalah cara fisiologis dalam perawatan tali pusat dan pengkleman tali pusat secara dini merupakan intervensi yang masih memerlukan pembuktian lebih lanjut.

Dengan semakin cepat penyembuhan atau waktu puput tali pusat berarti semakin sedikit waktu perawatan tali pusat sehingga semakin rendah risiko infeksi yang terjadi pada tali pusat. Banyak juga ibu-ibu yang belum berani memandikan bayi mereka apabila tali pusat belum puput, semakin cepat puput tali pusat maka ada kemungkinan ibu-ibu akan lebih percaya diri dalam memberikan perawatan kepada bayinya.

\section{Penundaan Pemotongan Tali Pusat Terhadap Lama Plasenta Lahir}

Berdasarkan hasil penelitian di dapatkan bahwa ibu bersalin dengan penundaan pemotongan tali pusat akan mengalami lama lepas plasenta kurang dari atau sama dengan 5 menit sebanyak $28 \%$ dan yang lebih dari 5 menit sebanyak 31\% sedangkan ibu bersalin yang segera dipotong tali pusatnya akan mengalami lepas plasenta dalam waktu kurang dari atau sama dengan 5 menit sebanyak 72\% dan yang lebih dari 5 menit sebanyak 38\%. Ibu bersalin dengan penundaan pemotongan tali pusat 0.6 kali lebih cepat lahir dibandingkan dengan ibu bersalin yang segera dipotong tali pusatnya dengan RR 0.6 (95\% CI 0.239-1.160). Manajemen aktif kala III untuk mempercepat kelahiran plasenta dan dapat mencegah atau mengurangi risiko perdarahan post partum. Manajemen aktif kala III telah dimasukkan kedalam Asuhan Persalinan Nornal (APN) dengan mengklem tali pusat dan menyuntikkan 10 unit oksitosin 2 menit setelah bayi lahir (Saifudin, 2007). Selain manajemen aktif kala III ada juga manajemen fisiologis persalinan kala III atau penundaan pengkleman tali pusat sampai tali pusat berhenti berdenyut. Untuk mengklem dan memotong tali pusat pada semua bayi tanpa memandang usia kehamilan dan berat badan bayi. Dengan adanya Manajemen Aktif Kala III diharapkan dapat mempercepat kelahiran plasenta sehingga dapat juga mengurangi risiko perdarahan post partum. Akan tetapi manajemen fisiologis persalinan kala III yaitu dengan penundaan pemotongan tali pusat atau membiarkan saja plasenta terlahir tanpa intervensi juga memberikan keuntungan berupa adanya transfer darah dari plasenta sekitar 80 $100 \mathrm{ml}$ pada 3 menit setelah bayi lahir, meningkatkan kadar hematokrit dan bilirubin dan meningkatkan oksigen.

\section{Penundaan Pemotongan Tali Pusat Terhadap Lama IMD}

Berdasarkan hasil penelitian di dapatkan bahwa ibu bersalin dengan penundaan pemotongan tali pusat akan melakukan Inisiasi Menyusu Dini (IMD) selama 60 menit sebanyak 42.2\% dan tidak ada yang melakukan IMD kurang dari 60 menit sedangkan ibu bersalin yang segera dipotong tali pusatnya yang melakukan IMD selama 
60 menit sebanyak 57.8\%. Ibu yang melakukan IMD selama 60 menit akan 0.5 kali berhasil memberikan ASI eksklusif dibandingkan dengan ibu yang tidak melakukan IMD atau IMD kurang dari 60 menit dengan RR 0.578 (95\% CI 0.484-0.689) Inisiasi Menyusu Dini (IMD) merupakan permulaan atau sebagai langkah awal untuk keberhasilan dalam pemberian ASI eksklusif. Munawaroh (2010), menyatakan bahwa 43\% ibu yang berhasil melakukan Inisiasi Menyusu Dini (IMD) akan berhasil juga dalam pemberian ASI eksklusif . Penundaan pemotongan tali pusat akan memberikan peluang kepada ibu yang melahirkan untuk dapat melakukan Inisiasi Menyusu Dini (IMD) sehingga bayi akan mendapatkan ASI lebih awal dan hal ini akan mempengaruhi terhadap keberlangsungan pemberian ASI eksklusif. Pemberian ASI eksklusif sudah terbukti banyak keuntungannya, salah satunya adalah bayi tidak mudah sakit karena ASI mempunyai kandungan antibodi.

\section{HASIL DAN PEMBAHASAN}

Tabel 1 menunjukkan bahwa bayi dari ibu dengan penundaan pemotongan tali pusat akan mengalami puput tali pusat selama kurang dari atau sama dengan 5 hari sebanyak $54.4 \%$ sedangkan bayi dari ibu yang segera dipotong tali pusatnya sebanyak $45.5 \%$. Ibu bersalin dengan penundaan pemotongan tali pusat akan mengalami pelepasan plasenta selama kurang dari 5 menit sebanyak 28\% dan ibu bersalin yang segera dipotong tali pusatnya sebanyak $72 \%$. Ibu bersalin dengan penundaan pemotongan tali pusat akan melakukan IMD selama 60 menit sebanyak $42.2 \%$ dan ibu bersalin yang segera dipotong tali pusatnya sebanyak $57.8 \%$.

\section{KESIMPULAN}

Masih banyaknya ibu yang melahirkan dengan tanpa penundaan pemotongan tali pusat yang disebabkan masih sedikit pilihan tempat melahirkan dengan penundaan pemotongan tali pusat; Ibu yang melahirkan dengan penundaan pemotongan tali pusat plasentanya akan lahir 0.6 kali lebih cepat dibandingkan dengan ibu melahirkan yang segera dipotong tali pusatnya; Ibu yang melahirkan dengan penundaan pemotongan tali pusat akan mengalami puput pada tali pusat lebih cepat 1.5 kali dibandingkan dengan ibu yang melahirkan segera dipotong tali pusatnya; Ibu yang melahirkan dengan penundaan pemotongan tali pusat akan lebih berhasil melakukan Inisiasi Menyusu Dini (IMD) selama 60 menit sebesar 0.5 kali dibandingkan dengan ibu melahirkan yang segera dipotong tali pusatnya. Saran metode penundaan pemotongan tali pusat merupakan cara persalinan alamiah tanpa menggunakan alat dan dapat dilakukan oleh bidan dimanapun termasuk pada saat terjadi kegawatdaruratan; Banyak manfaat yang diperoleh untuk bayi dan ibunya sehingga tidak ada alasan untuk tidak mencoba penerapan metode persalinan alamiah ini; Melakukan penundaan pemotongan tali pusat merupakan pilihan ibu yang akan melahirkan, peningkatan pengetahuan calon ibu perlu ditingkatkan untuk melakukan metode ini. 


\section{DAFTAR PUSTAKA}

1. Aprillia, Yesie, 2014, Penundaan pengkleman dan Pemotongan Tali pusat (Delayed Cord Clamping), artikel, Bidan Kita.

2. Febrina, 2011, Kelahiran Lotus (Lotus Birth), artikel, bidan shop

3. Buckley, Sarah, 2009, Gentle Birth, Gentle mothering: A Doctor's Guide to NaturalChildbirth and Gentle Early Parenting Choices, new York: Celestial Arts.

4. Kartika, Unoviana, 2013, Lotus Birth, PersalinanTanpaMemotongTaliPusat, artikel, Kompas.

5. Kautsar, Ummu, 2009, EfekPenjepitan Dan PemotonganTaliPusatTertunda, artikel

6. Tiara, 2013, ManajemenFisiologis Kala III atauTeknikPenundaanPemotonganTaliPusat

7. Mercer, 2001, Current Best Evidence: a Review of The Literature on Umbilical Cord Clamping.J Midwifery Womens Health.

8. Mercer, 2006, Delayed Cord Clamping in Very Preterm Infants Reduces the Incidence of Intraventricular Hemorrhage and Late-Onset Sepsis: A randomized, Controlled Trial. Pediatrics , Vol.117 No.4, Page 1235-1242

9. Munawaroh, 2011, Pengaruh ASI Segera Terhadap Pemberian ASI Eksklusif di Indonesia 2010 (Analisis Data Riskesdas 2010), Tesis, Universitas Indonesia

10. Ratnasari dkk, 2013, Pengaruh Persalinan Lotus Birth Terhadap Lama PelepasanPlasenta, Lama Pelepasan Tali Pusat dan Keberhasilan Bounding Attachment, jurnal Kebidanan, vol.v, no.02, Desember 2013

11. Wahyuningsih, Merry, 2012, Melahirkan ala Lotus Birth, Banyak Plusnya atau Minusnya? Artikel, detik Health. 